\title{
CLASSIFICATION OF STRATEGIES FOR SOCIO-ECONOMIC DEVELOPMENT OF UNITED TERRITORIAL COMMUNITIES
}

\author{
NADIYA PYLYPIV, IRYNA PIATNYCHUK, SVIATOSLAV SOLOGUB
}

\begin{abstract}
The article deals with the classification of strategies for socio-economic development of united territorial communities in a dynamic business environment. The purpose of the article is to build a classification of strategies for socio-economic development of the united territorial communities to increase the effectiveness of their development and implementation in practice. Based on the conducted research, the author's vision of defining the essence of 'socio-economic development of united territorial communities' was formed. It will contribute to a clearer understanding of this category. We defined the characteristics that determine the socio-economic development of the united territorial community. We evaluated the dynamics of the process of creating territorial communities in Ukraine and identified opportunities for creating new communities. To build a strategy for the socio-economic development of united territorial communities that would meet the requirements of the modern business environment, as well as satisfy the expectations that are set for it, we systemized various types of strategies into classification groups. Among them: development strategies, strategies of management and utilization of united territorial communities resources, gender-oriented strategies, strategies to counter, strategies of the development of the economic sectors, strategies of the development of UTC areas, digitalization strategies, communication and information strategies, management strategies, European integration strategies. The developed classification of strategies will contribute to a more accurate formation of strategic goals and actions, and contribute to the effective implementation and realization of the developed strategy of united territorial communities. The obtained results of the study serve as the basis for subsequent research in terms of ensuring the socio-economic development of united territorial communities.
\end{abstract}

Keywords: strategy, socio-economic development, sustainable development, united territorial communities, classification groups of strategies.

JEL Classification: R58, Q01.

\section{INTRODUCTION}

The current state of implementation of reforms in Ukraine largely depends on the processes of decentralization, which form a new system of local self-government, through which territorial communities are given the authority to use resources, have access to services to meet the needs of citizens. Identification of priority directions and ways of development of the united territorial community is declared in the strategy of socio-economic development. 
It should be noted that its formation should be carried out in accordance with the concept of sustainable development, which is associated with improving the quality of all spheres of human life. [1, p. 376]. Therefore, taking into account the social, environmental and economic priorities of sustainable development will contribute to the socio-economic development of the united territorial community to meet the needs of all interested parties: society, business and the state.

It is impossible to ensure the practical implementation of the socio-economic development strategy of the united territorial community without considering the types of such strategies and identifying them. Therefore, there is a need to conduct a study on classifications of strategies for socio-economic development of united territorial communities to ensure their effective implementation in the modern business environment through compliance with the concept of sustainable development.

\section{THEORETICAL BACKGROUND}

Before investigating the classification of strategies for socio-economic development of united territorial communities, we consider it necessary to review the literature. As a result of studying scientific sources, it is established that the term 'socio-economic development' characterizes the relationship between the degree of economic development and the solution of socially significant problematic issues of society and business entities operating in it. This definition also includes transformational processes in the relations of economic entities with various social population groups within the framework of the concept of sustainable development [2].

Some publications emphasize that it is possible to ensure the sustainable development of united territorial communities if social responsibility is introduced, which covers such areas as respect for human rights; compliance with the law; business and corporate ethics; environmental protection; cooperation with stakeholders; compliance with international standards of conduct; care for the elderly; transparency and reporting [3, p. 129].

It is worth mentioning that according to the ISO 26000 social responsibility standard, 'social responsibility is the responsibility of an organization for the impact of its decisions and activities on society and the environment, acting ethically and transparently, which contributes to the health and well-being of society; takes into account the expectations of stakeholders and complies with current legislation; meets international standards of conduct and is integrated into the activities of the entire organization' (ISO, 2018b) [4, p. 37].

It is also investigated that scientists distinguish two points of view on the essence of regional development:

- according to the first one, 'regional development is a multidimensional process, usually considered as a set of different social and economic goals. According to M. Buianova, it is understood as the functioning mode of the regional system, focused on the positive dynamics of the parameters of population's level and quality of life, ensured by a stable and balanced reproduction of the social, economic, resource and ecological potentials of territories' [5, p. 20];

- according to the second, in the view of T. Skufina, 'it should be understood as any, not necessarily progressive, changes in economic and social components according to STP, the growing influence of interregional and intersectoral competition, the growing importance of public administration of macro, meso and microeconomic processes' [5, p. 33].

Scientists also emphasize that in general, sustainable development should be considered within a single country, region or enterprise in the context of three components: economic, social and environmental [6, p. 206]. This fact has a direct impact on the classification of strategies, including strategies for the socio-economic development of united territorial communities. 


\section{Research Objective, Methodology and Data}

To confirm our hypothesis, we studied the scientific works of leading researchers and strategic documents that form strategic goals for the socio-economic development of communities, taking into account sustainable development. We analyzed: 1) scientific publications in journals indexed by Scopus the international scientific metric database. We considered only qualitative studies, the results of which were published in high-level scientific publications, and therefore cited by other researchers; 2) community development strategies; 3) public sphere development strategies. As for them, we analyzed the content of national and regional strategies and countries associations to implement the best ones in Ukrainian practice. It can also be useful for countries with similar levels of socio-economic development.

The results presented in the article will encourage further research and help in the development of strategies for the socio-economic development of united territorial communities.

\section{RESUlTS AND Discussion}

The study of special literature of research economists regarding the existing positions on identifying the essence of socio-economic development allowed us to form the following author's interpretation of the definition of socio-economic development of a united territorial community.

Socio-economic development of a united territorial community is a purposeful, natural change in the economic state of a united territorial community through solving socially significant problems aimed at observing the concept of sustainable development in a modern changing business environment, as a result of which the community moves to a new qualitative state. The results presented in the article will encourage further research and help in the development of strategies for the socio-economic development of united territorial communities.

It should be noted that only the simultaneous presence of all three of the following characteristics distinguishes development processes from other changes. Those are:

- cyclic reproduction of a permanent functioning system;

- the presence of development regularities with clearly defined strategic directions;

- there is a single line of priorities in different areas, which has a cumulative effect.

In our opinion, the characteristics that determine the socio-economic development of a united territorial community (hereinafter UTC) should be considered:

- changes in the economic sphere - quantitative characteristics in the development of the territorial community economic system, which provides an opportunity to assess the development of small and medium-sized businesses, overcoming poverty, the efficiency of using energy resources; the efficiency of using budget funds, investments, grants, other types of financial support; the amount of funding for the implementation of the UTC social responsibility program, etc.;

- changes in internal business processes within the UTC (in particular, the management process, main and security processes), which provide an assessment of trends in the effectiveness of the implementation of the UTC's socio-economic development strategy, the success of achieving sustainable development goals, the implementation of decisions by the management personnel of the UTC; the quality of services provided by suppliers (educational, cultural, medical institutions, etc.) and enterprises that operate on the territory of the UTC; the functioning provision of the UTC with the necessary resources; the budgeting process [7, p. 229; 8, p. 301];

- changes in the social sphere - assessment of the implementation of UTC social responsibility program, satisfaction of the community population and their well-being, in particular in terms of social living conditions, the quality of social services received, the level of consumers satisfaction and their well-being. It makes possible to assess the level of social responsibility of UTC to society in the context of the implementation of sustainable development goals; 
- changes in the environmental sphere - the impact of enterprises 'activities in the territory of UTC on the environment, compliance with environmental requirements and enterprises' activities, which will affect their business reputation and competitiveness [3, p. 134].

Changes in the above areas can be estimated using a balanced system of indicators, which can act as an analytical tool for ensuring the implementation of socio-economic development strategy of UTC in the context of the concept of sustainable development.

Given the subject of our research, we consider it necessary to diagnose the state of the UTC creation process.

At the same time, it should be noted that a united territorial community (UTC) is a voluntary association of residents on a contractual basis of several disparate villages, towns or cities into one administrative and command center. After consolidation, a new administrative center is formed, within which local self-government bodies are created and carry out their activities.

The law of Ukraine 'On Voluntary Unification of Territorial Communities' is the primary and main regulatory document regulating the process of creating a united community [9]. It is important to note that the formation of UTC is impossible without the decentralization reform.

It is established that united communities are formed in accordance with the need of economic efficiency and development of geographically adjacent villages, towns, and cities. A united territorial community with an administrative center in a city can be called an urban territorial community, and a community with a center in an urban type settlement can be called a settlement community, and a community with a center in a village can be called a village community.

The newly created territorial community receives the resources of all combined localities and corresponding powers on its balance sheet. It should be noted that during the merger, the newly created association conducts independent economic activities and directly cooperates with the city budgets and the state budget of Ukraine, and without direct subordination to the mayor. The newly created association has the right to determine the direction of its activities, search for investors and independently distribute profits to the community's own needs.

It is established that as of 10.01.2020, 1029 UTC with a population of 11.7 million people were created in Ukraine. Long-term plans for the formation of community territories cover $90.3 \%$ of the country's territory in 12 countries [10]. The dynamics of creating the number of UTCs in Ukraine in 2015-2019 is shown at Fig. 1.

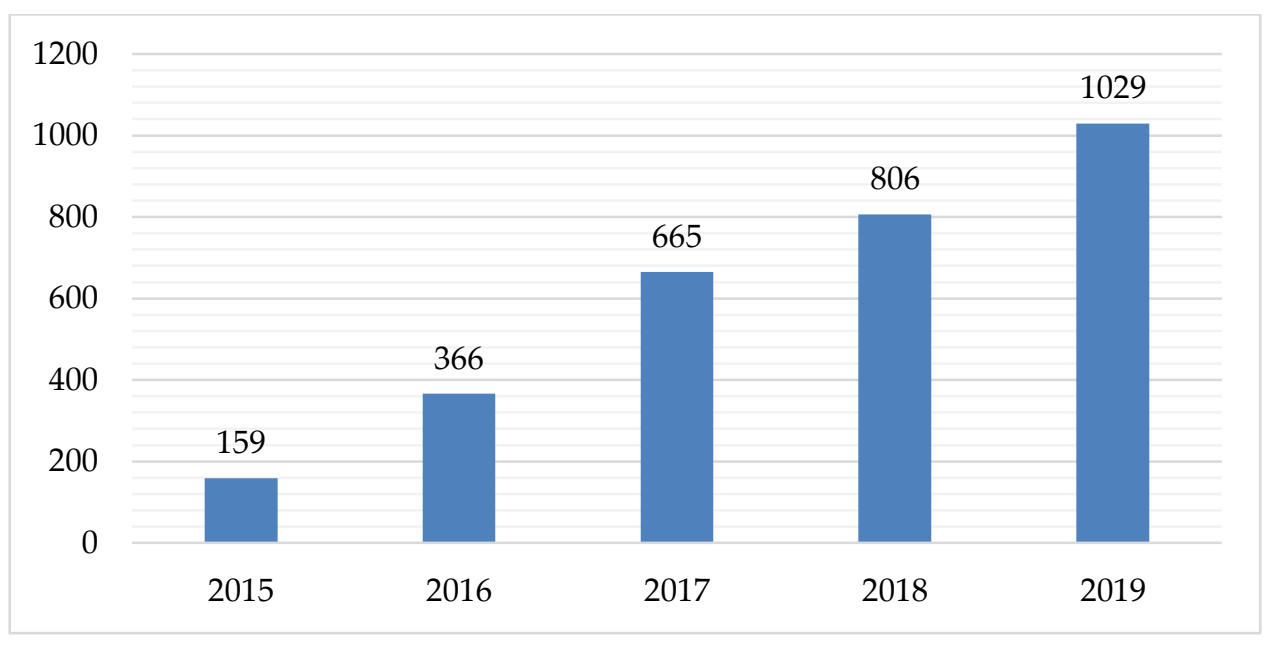

Fig. 1. Dynamics of the UTC number in Ukraine in 2015-2019. Source: [10].

Based on the monitoring of the process of power decentralization and local self-government reform, the Ministry for Communities and Territories development of Ukraine has formed a rating of regions for the formation of capable communities in terms of the overall rating and place according to the parameters shown in Tab. 1. 


\begin{tabular}{|c|c|c|c|c|c|c|c|c|}
\hline \multirow[b]{2}{*}{ Region } & \multirow[b]{2}{*}{ 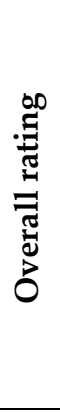 } & \multicolumn{7}{|c|}{ Capable Local Communities Rating } \\
\hline & & 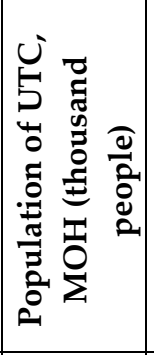 & 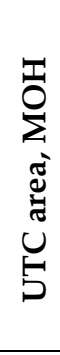 & 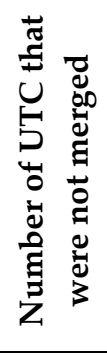 & 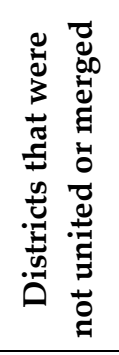 & 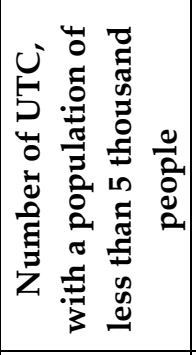 & 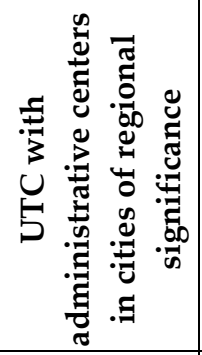 & 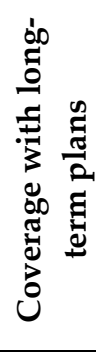 \\
\hline Zhytomyк & 1 & 5 & 3 & 3 & 1 & 11 & 3 & 3 \\
\hline Dnipropetrovsk & 2 & 2 & 2 & 2 & 1 & 16 & 7 & 1 \\
\hline Chernihiv & 3 & 4 & 4 & 4 & 1 & 14 & 2 & 4 \\
\hline Khmelnytsk & 4 & 8 & 5 & 5 & 2 & 9 & 4 & 1 \\
\hline Zaporizhzhia & 5 & 3 & 1 & 1 & 1 & 19 & 9 & 1 \\
\hline Volyn & 6 & 10 & 6 & 6 & 1 & 12 & 6 & 1 \\
\hline Sumy & 7 & 9 & 12 & 12 & 3 & 10 & 1 & 2 \\
\hline Donetsk & 8 & 1 & 11 & 11 & 16 & 5 & 9 & 1 \\
\hline Chernivtsi & 9 & 14 & 8 & 10 & 7 & 6 & 2 & 11 \\
\hline Ternopil & 10 & 16 & 9 & 8 & 4 & 17 & 2 & 6 \\
\hline Mykolaiv & 11 & 6 & 7 & 9 & 8 & 15 & 9 & 12 \\
\hline Luhansk & 12 & 7 & 10 & 7 & 10 & 22 & 11 & 1 \\
\hline Rivne & 13 & 21 & 15 & 14 & 9 & 8 & 2 & 1 \\
\hline Ivano-Frankivsk & 14 & 22 & 17 & 18 & 5 & 3 & 2 & 8 \\
\hline Kharkiv & 15 & 12 & 19 & 19 & 18 & 1 & 5 & 1 \\
\hline Poltava & 16 & 11 & 16 & 16 & 6 & 18 & 4 & 7 \\
\hline Kherson & 17 & 17 & 14 & 13 & 13 & 20 & 2 & 10 \\
\hline Cherkasy & 18 & 15 & 13 & 15 & 2 & 21 & 10 & 15 \\
\hline Odesa & 19 & 13 & 18 & 17 & 16 & 6 & 8 & 17 \\
\hline Kyiv & 20 & 18 & 22 & 20 & 15 & 4 & 4 & 16 \\
\hline Lviv & 21 & 20 & 21 & 22 & 12 & 7 & 11 & 13 \\
\hline Zakarpattia & 22 & 24 & 24 & 24 & 14 & 2 & 9 & 9 \\
\hline Vinnytsia & 23 & 23 & 23 & 21 & 11 & 13 & 2 & 14 \\
\hline Kirovohrad & 24 & 19 & 20 & 23 & 17 & 23 & 11 & 5 \\
\hline
\end{tabular}

Tab. 1. Capable Local Communities Rating. Source: [11].

In particular, the data in the table shows that the Ivano-Frankivsk region is on the 14th place in this rating and has 18 more territorial communities that have not been merged. And in general, for all regions in Ukraine, there are only 300 territorial communities that have not been united.

As a result of studying analytical information on the rating of regions about the formation of capable communities, quite significant opportunities for creating new communities have been identified, and this indicates the need to develop strategies for their socio-economic development. So, the question of classifying such strategies for the development of UTC in the context of ensuring sustainable development not only in the region but also in the country as a whole is relevant.

The conducted empirical research allowed us to establish that the development of a strategy for the socio-economic development of UTC begins with the preparation of a regulatory document, which should indicate all strategic goals, methods and means for their implementation. This document should indicate priority areas of activity, taking into account the available financial, technical, information and human resources, which should contribute to the sustainable development of the community for the relevant strategic period.

The strategy is considered as the main regulatory document, not only in the economic direction but also in the social one, which focuses on the rational use of human potential, technology, financial and 
natural resources due to the effective management of a local government body, which is based on the effective implementation of the main priority areas defined by such a strategy [2].

In order to develop a strategy for the socio-economic development of UTC that would meet the requirements of the modern business environment, as well as meet the expectations that are set for it, we consider it necessary to study the types of such strategies.

As a result of studying the specialized literature, there was no systematic classification of types of strategies for socio-economic development of UTC. However, the empirical study allowed us to identify various strategies that have been developed and implemented in the practical activities of the subject. Therefore, we have systematized such strategies and grouped them into classification groups (Table 2): development strategies, strategies of management and utilization of united territorial communities resources, gender-oriented strategies, strategies to counter, development of the economic sector's strategies, strategies of development of united territorial communities areas, digitalization strategies, communication and information strategies, management strategies, European integration strategies.

\begin{tabular}{|c|c|}
\hline Classification group & Types of strategies \\
\hline \multirow{4}{*}{ Development strategies } & Investment development strategy \\
\hline & Innovative development strategy \\
\hline & Sustainable development strategy \\
\hline & Balanced development strategy \\
\hline \multirow{4}{*}{$\begin{array}{l}\text { Strategies of management and } \\
\text { utilization of UTC resources }\end{array}$} & Resource and financing mobilization strategy \\
\hline & Resource-saving strategy \\
\hline & UTC population development strategy \\
\hline & Environmental protection strategy \\
\hline \multirow{2}{*}{ Gender-oriented strategies } & Gender strategy \\
\hline & Gender equality and non-discrimination strategy \\
\hline \multirow{5}{*}{ Strategies to counter } & Anti-bullying strategy \\
\hline & Anti-discrimination strategy \\
\hline & Strategy on organized crime \\
\hline & Anti-Corruption Strategy \\
\hline & Strategy on global environmental pollution \\
\hline $\begin{array}{l}\text { Strategies of development of } \\
\text { economic sectors }\end{array}$ & $\begin{array}{l}\text { Strategies for the development of economic sectors (electric power, fuel, } \\
\text { ferrous and non-ferrous metallurgy, chemical and petrochemical, machine- } \\
\text { building, metalworking, forestry, woodworking, light, food and others) }\end{array}$ \\
\hline $\begin{array}{l}\text { Strategies of development of } \\
\text { UTC areas }\end{array}$ & $\begin{array}{l}\text { Strategy for the development of education, medicine, culture, sports, } \\
\text { entrepreneurship, tourism, infrastructure, and other areas at the UTC level }\end{array}$ \\
\hline \multirow{4}{*}{ Digitalization strategies } & Digital strategy \\
\hline & Cloud strategy \\
\hline & Cybersecurity strategy \\
\hline & Digital transformation strategy \\
\hline \multirow{4}{*}{$\begin{array}{l}\text { Communication and } \\
\text { information strategies }\end{array}$} & PR strategy \\
\hline & Communication strategy \\
\hline & Information strategy \\
\hline & Media strategy \\
\hline \multirow{3}{*}{ Management strategies } & Management modernization strategy \\
\hline & Management reform strategy \\
\hline & Change response strategy \\
\hline \multirow{3}{*}{ European integration strategies } & Communication strategy in the field of European integration \\
\hline & Information and communication strategy for European integration \\
\hline & European integration strategy \\
\hline
\end{tabular}

Tab. 2. Classification of socio-economic development strategies of UTC. Source: compiled by the authors. 
The classification group 'Development Strategies' includes strategies for the socio-economic development of UTC that provide for the appropriate direction in the development of the community, namely the strategy: investment development, innovative development, sustainable development, balanced development. If investment, innovation and sustainable development strategies are widely used and understandable, then a balanced development strategy requires additional explanation.

The study shows that the strategy of balanced development of UTC in the literature is proposed to understand as a long-term qualitatively defined direction of development, based on a set of systematized actions that allow us to determine the most appropriate tools and measures for implementing procedures, parameters and processes of socio-economic development of UTC based on strategic priorities. Such a strategy requires the formation of new scientific approaches and practical actions that meet not only modern conditions, but also provide for the prospects for socio-economic development of UTC [5, p. 35].

The classification group 'Strategies for managing and using UTC resources' includes strategies that are aimed at improving the efficiency of available financial and natural resources use, developing the population and protecting the environment of UTC.

The classification group 'Gender-oriented strategies' includes strategies that are currently being implemented in the country and extend to the level of UTC and are focused on promoting gender priorities, improving the efficiency of using community budget funds depending on its needs, applying gender-oriented budgeting and introducing non-discrimination.

The classification group 'Strategies to counter' was formed by strategies that are focused on eliminating the negative manifestations of the relevant phenomenon or process for the prevention and fight against bullying, discrimination, organized crime, corruption, and a strategy for combating global environmental pollution.

The classification group 'Strategies of the development of economic sectors' was formed by strategies aimed at the development of certain sectors of the economy at the UTC level, in particular: electric power, fuel, forestry, woodworking, light, food, etc.

The classification group 'Strategies of the development of UTC areas' includes strategies that are focused on the development of education, medicine, culture, sports, entrepreneurship, tourism, infrastructure, and other areas at the UTC level. It is to promote the development of the relevant areas, which are identified as strategically important for the relevant UTC.

The classification group 'Digitalization strategies' includes strategies that have recently begun to form as a response to the challenges of our time through the development of the digital economy, the creation of cybersecurity infrastructure, and determining the directions and tasks of digital transformation.

The classification group 'Communication and information strategies' is represented by strategies that are aimed at establishing communication links in UTC, using PR technologies to form a positive reputation of UTC and increase its competitiveness, as well as using media literacy technologies, which is also formed taking into account modern needs and challenges.

The classification group 'Management Strategies' includes strategies that provide for the application of an appropriate approach in the process of managing UTC through modernization and reform of public administration through the possibility of timely response to new changes. Such strategies should contribute to achieving a new quality level in UTC management.

The classification group 'European integration strategies' includes strategies for improving information/communication on European integration topics in society.

So, the above classification of strategies for socio-economic development of UTC will contribute to a more accurate formation of strategic goals and measures, as well as effective implementation, monitoring and implementation of the strategy of UTC, which will contribute to the economic development of communities, increase their social responsibility and environmental awareness. 


\section{CONCLUSIONS}

Thus, the conducted research on the formation of classification of strategies for socio-economic development of UTC began with the formation of the author's definition of the essence of socioeconomic development of UTC. Therefore, the socio-economic development of a united territorial community is a purposeful, natural change in the economic state and the solution of socially significant problems, aimed at observing the concept of sustainable development in a modern changing business environment, as a result of which the community moves to a new qualitative state.

Based on the understanding of the essence of socio-economic development, strategies are systematized and grouped into classification groups, such as: development strategies, strategies of management and utilization of UTC resources, gender-oriented strategies, strategies to counter, strategies of the development of economic sectors, strategies of the development of UTC areas, digitalization strategies, communication and information strategies, management strategies, European integration strategies. The developed classification groups of strategies for socio-economic development of UTC will contribute to improving the effectiveness of implementing of the appropriate strategy type, taking into account the needs of society and the challenges of the modern business environment.

The obtained results of the study serve as the basis for subsequent research in terms of ensuring the socio-economic development of UTC.

\section{REFERENCES}

[1] Pylypiv N.I., Piatnychuk I.D., Maksymiv Yu.V. Ensuring sustainable development of the enterprise by modern tools of strategic management: the concept of business administration. Proc. of the Intern. Conf. "Theory and Practice of Strategic Management of Industrial and Regional Social Systems", IFNTUOG, Ivano-Frankivsk, Ukraine, October 11-13, 2017, IFNTUOG, Ivano-Frankivsk, 2017, 376-379. (in Ukrainian)

[2] Tyukha I.V. Socio-economic development of the enterprise: essence and species manifestations. Efficient Economics, 6 (2012). Available at: http://www.economy.nayka.com.ua/?op=1\&z=1195 (in Ukrainian)

[3] Pylypiv N., Piatnychuk I., Halachenko O., Maksymiv Yu., Popadynets N. Balanced scorecard for implementing united territorial communities' social responsibility. Problems and Perspectives in Management, 18 (2) (2020), 128-139. doi:10.21511/ppm.18(2).2020.12

[4] Pylypiv N.I., Piatnychuk I.D., Sologub S.I. Concept of ATC social responsibility in the context of sustainable development. Bulletin of the Precarpathian University. Series: Economics, 13 (2018), 36-42. Available at: http://lib.pnu.edu.ua:8080/handle/123456789/2531 (in Ukrainian)

[5] Dubnytsky V.I., Komirna V.V., Ganzhela I.P. Strategy of development of social infrastructure of the region: model, regularities, arguments, urgency, result. Social economy, 1 (2016), 30-38. Available at: http://nbuv.gov.ua/UJRN/se_2016_1_6 (in Ukrainian)

[6] Pylypiv N.I., Piatnychuk I.D., Maksymiv Yu.V. Conceptual approach to construction of accounting and information provision of social responsibility for business enterprises through the prism of the business partnership system. Financial and credit activity: problems of theory and practice, 27 (2018), 201-211. Available at: http://lib.pnu.edu.ua:8080/handle/123456789/1910

[7] Piatnychuk I.D. Systematization of approaches to determining the principles and methods of budgeting. Scientific and Information Bulletin of Ivano-Frankivsk University of Law named after King Danylo Halytsky, 12 (2015), 228-236. Available at: http://nbuv.gov.ua/UJRN/Nivif_2015_12_34 (in Ukrainian)

[8] Piatnychuk I.D. Categorical apparatus and tools of the budgeting system. Scientific and Information Bulletin of Ivano-Frankivsk University of Law named after King Danylo Halytsky, 9 (2014), 298-304. (in Ukrainian) 
[9] Law of Ukraine "On Voluntary Association of Territorial Communities". The Verkhovna Rada of Ukraine, № 157-VIII of February 5, 2015. Available at: https://zakon.rada.gov.ua/laws/show/157VIII\#Text (in Ukrainian)

[10] What happened in the development of communities and territories in 2019 - data from the monitoring of decentralization. Portal "Decentralization", (2020). Available at: https://decentralization.gov.ua/news/12055. (in Ukrainian)

[11] Monitoring the process of decentralization of power and reform of local self-government. Ministry of Development of Communities and Territories of Ukraine. Kyiv, 2020. Available at: https://decentralization.gov.ua/mainmonitoring (in Ukrainian)

Address: Nadiya Pylypiv, Iryna Piatnychuk, Sviatoslav Sologub, Vasyl Stefanyk Precarpathian National University, 57 Shevchenko St., Ivano-Frankivsk, 76018 Ukraine;

E-mail: npylypiv@gmail.com, iryna.piatnychuk@pnu.edu.ua, solohubsi@gmail.com

Received: May 14, 2020; revised: August 2, 2020.

Пилипів Надія, П'ятничук Ірина, Сологуб Святослав. Класифікація стратегій соціально-економічного розвитку об'єднаних територіальних громад. Журнал Прикарпатського університету імені Василя Стефаника, 7 (3) (2020), 27-35.

У статті розглянуто питання класифікації стратегій соціально-економічного розвитку об'єднаних територіальних громад в умовах динамічного бізнес-середовища. Метою статті є розробити класифікацію стратегій соціально-економічного розвитку об'єднаних територіальних громад для підвищення ефективності їх розробки та імплементації у практичну діяльність. На основі проведеного дослідження сформовано авторське бачення визначення сутності "соціальноекономічний розвиток об'єднаних територіальних громад”, що сприятиме більш чіткому розумінню цієї категорії. Виокремлено Характеристиками, які визначають соціально-економічний розвиток об'єднаної територіальної громади. Проведено оцінку динаміки процесу створення територіальних громад в Україні та виявлено можливості щодо створення нових громад. 3 метою розробки стратегії соціально-економічного розвитку об'єднаних територіальних громад, яка б відповідала вимогам сучасного бізнес-середовища, а також задоводьняла очікування, які перед нею ставдяться, здійснено систематизацію різних видів стратегій у класифікаційні групи, такі, як: стратегії розвитку, стратегії управління і використання ресурсів об'єднаних територіальних громад, гендерно-орієнтовані стратегії, стратегія боротьби, стратегії розвитку галузей економіки, стратегії розвитку сфер об'єднаних територіальних громад, стратегії діджиталізації, комунікаційно-інформативні стратегії, стратегії управління, евроінтеграційні стратегії. Розроблена класифікація стратегій соціально-економічного розвитку об'єднаних територіальних громад сприятиме більш точному формуванню стратегічних цілей, заходів та сприяти ефективному впровадженню і реалізації розробленої стратегії об'єднаних територіальних громад. Отримані результати проведеного дослідження виступають основою для наступних досліджень у частині забезпечення соціально-економічного розвитку об'єднаних територіальних громад.

Ключові слова: стратегія, соціально-економічний розвиток, сталий розвиток, об'єднані територіальні громади, класифікаційні групи стратегій. 